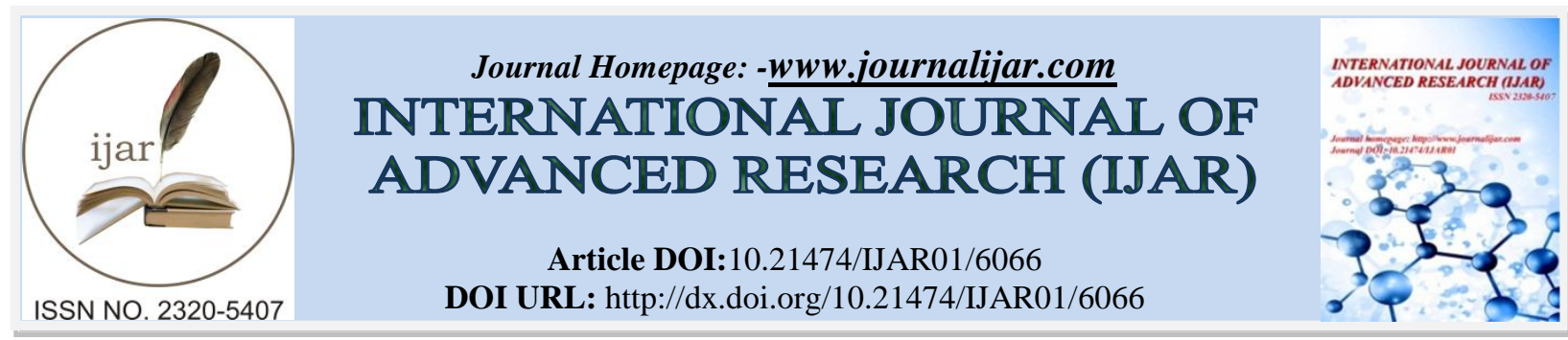

RESEARCH ARTICLE

\title{
THE STUDY OF THE PHYSICO-CHEMICAL QUALITY OF DESALINATED SEAWATER BY REVERSE OSMOSIS (CASE OF THE NOUAMGHAR SEAWATER DESALINATION UNIT IN MAURITANIA).
}

\section{Mohamed LemineOuld Mohamed El Moustapha ${ }^{1}$, Said Ibn Ahmed ${ }^{1}$ and Mohamed LemineFajel ${ }^{2}$.}

1. Materials, Electrochemistry and Environment Laboratory, Faculty of Sciences, University IbnTofailKenitra, Morocco.B.P: 133.

2. Center for Applied Research on Renovable Energies, Faculty of Science and Technology University of Nouakchott Moderne Nouakchott Mauritania.

\section{Manuscript Info}

\section{Manuscript History}

Received: 15 October 2017

Final Accepted: 17 November 2017

Published: December 2017

Key words:-

Seawater, Desalination, Reverse

Osmosis, Nouamghar, Mauritania.

\section{Abstract}

The study concerns the analysis of the physico-chemical quality of desalinated seawater by reverse osmosis (case of the Nouamghar seawater desalination unit in Mauritania).

The results of this study show that the $\mathrm{pH}$ is close to neutrality with an average value of 6.95 , that of the average turbidity is $0.48 \mathrm{NTU}$, the average value of the TDS(Total Disolved Salts) is $0.61 \mathrm{~g} / \mathrm{L}$, the conductivity registered average electrical current is $1281.66 \mu \mathrm{s} / \mathrm{cm}$, the concentrations of nitrogen compounds are low, the mean values of hardness (TH), ions calcium, magnesium, sodium and potassium are respectively: $2.16{ }^{\circ} \mathrm{f}$, $3.87 \mathrm{mg} / \mathrm{L}, 2.91 \mathrm{mg} / \mathrm{L}, 73.16 \mathrm{mg} /$ Let $11.16 \mathrm{mg} / \mathrm{L}$, the average sulphate concentrations of chloride and bicarbonate are respectively $3.66 \mathrm{mg} / \mathrm{L}, 382.05 \mathrm{mg} / \mathrm{L}$ and $74.2 \mathrm{mg} / \mathrm{L}$.

Through this study, the problem of excess chloride and its health consequences on the population must be among the priority objectives.

Copy Right, IJAR, 2017,. All rights reserved.

\section{Introduction:}

More than $70 \%$ of the world's surface is covered by a reserve of 1.4 billion cubic kilometers of salt water. Collected, would represent a cube of more than 1000 kilometers of coast only about $0.6 \%$ of the water present on the surface of the globe is directly usable and soft. The rest is contained in the oceans but also trapped in the form of ice, a the state of water vapor in the atmosphere or remains simply inaccessible $(1,2)$.moreover, $36 \%$ of the world's population lives within 100 kilometers of a coastline, $11 \%$ within 10 kilometers, and $6 \%$ less than 5 kilometers away. Spreading sea water or brackish saline waters that are not salty but unsuitable for fresh water is a very attractive solution (3).

This is part of the Nouamghar reverse osmosis seawater desalination unit in Mauritania as a source of drinking water for the population of this coastal village.

Corresponding Author:-Mohamed LemineOuld Mohamed El Moustapha.

Address: Materials, Electrochemistry and Environment Laboratory, Faculty of Sciences, University IbnTofailKenitra, Morocco.B.P: 133. 


\section{Materials and methods:}

Site of study:

Nouamghar (or Nouâmghâr) is a coastal village and a commune in western Mauritania, located on the entrance of Cape Timiris (it is a cape of Mauritania located on the Atlantic Ocean, south of the island from Tidra) $(4,5)$ in the region of DakhletNouadhibou, on the border with that of Inchiri.

Its GPS cables are: $19^{\circ} 20^{\prime} 00$ " North and $16^{\circ} 32^{\prime} 00$ " West. This is one of the access points to Banc d'Argun National Park.

The population of Nouamghar is estimated at 4,151 inhabitants (6). The main activity for the inhabitants of this village is fishing.

The water supply is made by tanks coming from the capital of the country Nouakchott.

It is for this reason that the Mauritanian state has decided to install this reverse osmosis seawater desalination unit in this coastal village.

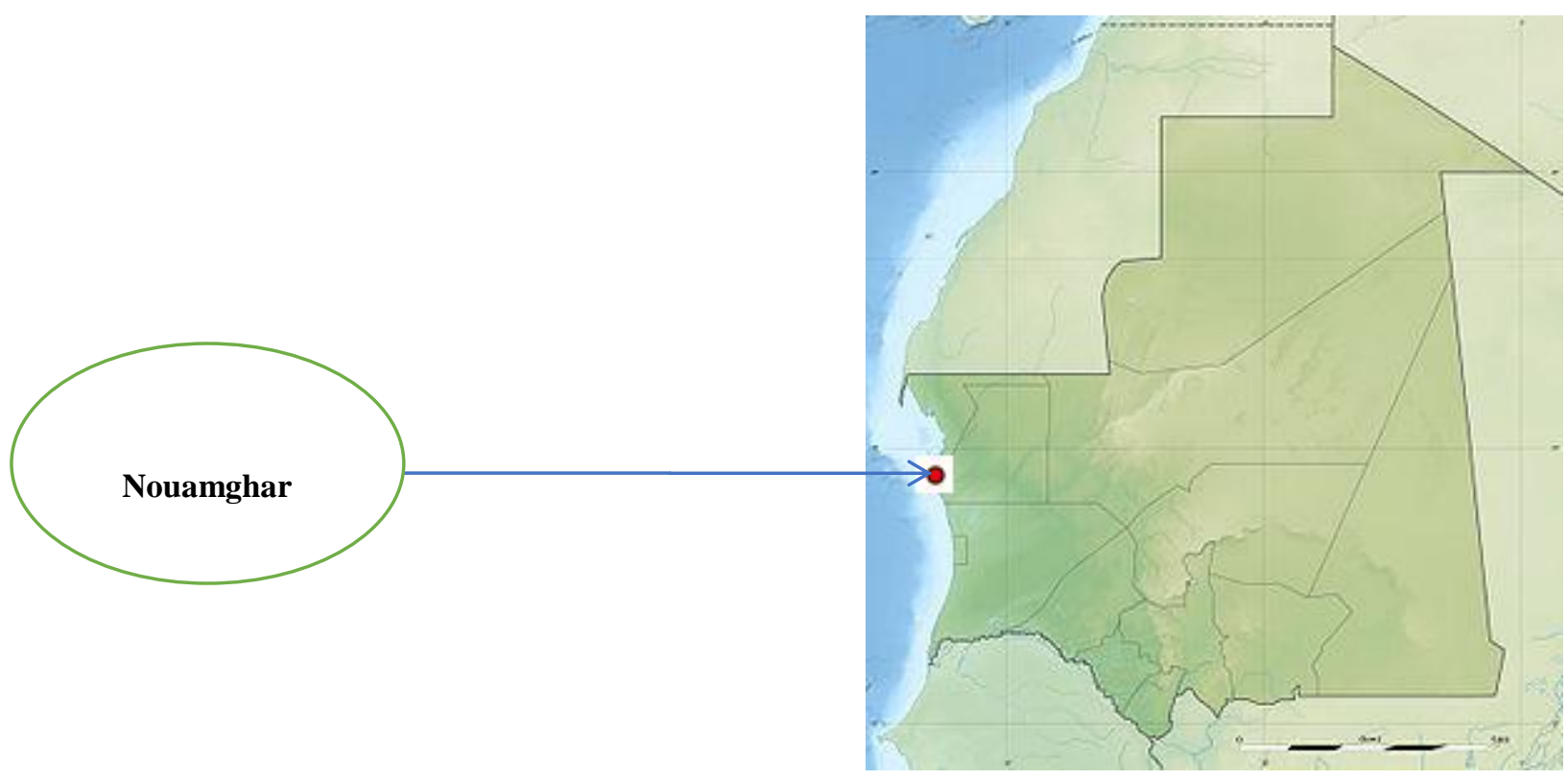

Figure 1:Location of Nouamghar on the map of Mauritania

\section{Sampling and analysis of produced water:}

The physicochemical parameters are determined from the monthly sampling (between April and May 2017) in polyethylene bottles with a capacity of $1 \mathrm{~L}$.

All the work was done on the Nouamghar seawater desalination unit.

Because of variations that may affect water samples, some parameters have been determined in situ: temperature, $\mathrm{pH}$, electrical conductivity, TDS and turbidity.

The rest of the evaluations were carried out by volumetric dosing or spectrophotometric assay, according to the analytical methods proposed by Rodier in the water chemistry laboratory at the National Institute of Public Health Research in Mauritania (7).

The parameters studied are:

Temperature,pH, Electrical Conductivity,TDS(Total Disolved Salts), Turbidity, Nitrates, Nitrites, Ammonium, Chlorides, Sulphates, Total Hardness, Calcium, Magnesium, Bicarbonates, Sodium, and Potassium. 
The $\mathrm{pH}$ and Temperature were determined by a Wagtech525043 $\mathrm{pH}$ meter equipped with a temperature measuring probe. The Electrical Conductivity was measured by a Wagtech 525043 type Conductivity meter. The Total Hardness, Chlorides, Calcium, Magnesium and Bicarbonates are determined by the volumetric method recommended by J. RODER. Nitrates, Nitrates, Ammonium and the Sulphates are determined by a UV-Vis Spectrophotometer type 7100. The Sodium and Potassium ions are determined by a Corning 410 Flame Spectrometer.

\section{Results:}

The assessment of the quality of the produced water of the Nouamghar seawater desalination unit was made according to the determination of a certain number of physicochemical parameters characterizing this water.

The physicochemical characteristics of the waters produced from this unit are summarized in Table 1.

Table 1: Physico-chemical parameters of reverse osmosis water from the Nouamghar seawater desalination unit in Mauritania.

\begin{tabular}{|l|l|l|l|l|}
\hline parameter & Min & Max & Average & Number of samples \\
\hline $\mathrm{T}\left({ }^{\circ} \mathrm{C}\right)$ & 28,8 & 31,2 & 30,5 & 6 \\
\hline $\mathrm{PH}$ & 5,47 & 8,4 & 6,95 & 6 \\
\hline $\mathrm{E} . \mathrm{C}(\mu \mathrm{S} / \mathrm{cm})$ & 1148 & 1450 & 1281,66 & 6 \\
\hline Turbudiy/NTU) & 0,38 & 0,67 & 0,48 & 6 \\
\hline TDS(Total Dissolved Salts) (g/L) & 0,574 & 0,653 & 0,61 & 6 \\
\hline $\mathrm{NO}_{2}{ }^{-}(\mathrm{mg} / \mathrm{L})$ & 0 & 0,02 & 0,01 & 6 \\
\hline $\mathrm{NO}_{3}{ }^{-}(\mathrm{mg} / \mathrm{L})$ & 0,06 & 0,86 & 0,37 & 6 \\
\hline $\mathrm{NH}_{4}{ }^{+}(\mathrm{mg} / \mathrm{L})$ & 0 & 0,01 & 0,001 & 6 \\
\hline $\mathrm{Cl}^{-}(\mathrm{mg} / \mathrm{L})$ & 355 & 426 & 381,03 & 6 \\
\hline $\mathrm{SO}_{4}{ }^{2-}(\mathrm{mg} / \mathrm{L})$ & 0 & 5 & 3,66 & 6 \\
\hline $\mathrm{Ca}^{2+}(\mathrm{mg} / \mathrm{L})$ & 2,4048 & 7,2 & 3,87 & 6 \\
\hline $\mathrm{Mg}^{2+}(\mathrm{mg} / \mathrm{L})$ & 1,944 & 3,88 & 2,91 & 6 \\
\hline${\mathrm{Total} \mathrm{Hardness}\left({ }^{\circ} \mathrm{f}\right)}^{+}{ }^{+}(\mathrm{mg} / \mathrm{L})$ & 1,40112 & 3,4 & 2,16 & 6 \\
\hline $\mathrm{K}^{+}(\mathrm{mg} / \mathrm{L})$ & 66 & 78 & 73,16 & 6 \\
\hline $\mathrm{HCO}_{3}^{-}(\mathrm{mg} / \mathrm{L})$ & 10 & 12 & 11,16 & 6 \\
\hline
\end{tabular}

The Temperature of the waters produced from the Nouamghar unit is between $28.8^{\circ} \mathrm{C}$ and $31.2^{\circ} \mathrm{C}$ as minimum and maximum extreme values and $30.5^{\circ} \mathrm{C}$ as mean value (Table 1 ).

In general, the samples of the produced water analyzed have a relatively neutral $\mathrm{pH}$.

For Electrical Conductivity, the recorded extreme values are between $1148 \mu \mathrm{S} / \mathrm{cm}$ and $1450 \mu \mathrm{S} / \mathrm{cm}$ with $1281.66 \mu \mathrm{S} / \mathrm{cm}$ as the average value (Table 1), The TDS values in produced waters are between $0.57 \mathrm{~g} / \mathrm{L}$ and $0.65 \mathrm{~g} / \mathrm{L}$ with $0.61 \mathrm{~g} / \mathrm{L}$ as average values,and those of Turbidity are between 0.38 NTU and 0.67 NTU with $0.48 \mathrm{NTU}$ as the average value.

While, the values found in Chlorides show that the waters produced from this unit are characterized by an average chloride concentration in the order of $381.03 \mathrm{mg} / \mathrm{L}$.

The Nitrate levels in the waters produced from this unit vary between $0.06 \mathrm{mg} / \mathrm{L}$ and $0.86 \mathrm{mg} / \mathrm{L}$ with an average value of about $0.37 \mathrm{mg} / \mathrm{L}$ (Table 1 ).

The values recorded in Sulphate vary between $0 \mathrm{mg} / \mathrm{L}$ and $5 \mathrm{mg} / \mathrm{L}$ with $3.66 \mathrm{mg} / \mathrm{L}$ as average value. 
The Calcium concentrations of the produced water analyzed vary between $0.40 \mathrm{mg} / \mathrm{L}$ and $7.20 \mathrm{mg} / \mathrm{L}$ with an average value of $1.83 \mathrm{mg} / \mathrm{L}$ (Table 1).

The Total Hardness of water (TH) is mainly related to the amount of calcium and magnesium in the water. In this study the TH varies between $1.40{ }^{\circ} \mathrm{f}$ and $3.40{ }^{\circ} \mathrm{f}$ with $2.16^{\circ} \mathrm{f}$ as the average value (Table $1)$.

The Sodium contents of the produced water analyzed vary between $66 \mathrm{mg} / \mathrm{L}$ and $78 \mathrm{mg} / \mathrm{L}$ with an average value of $73.16 \mathrm{mg} / \mathrm{L}$ (Table 1 ).

those of Potassium vary between $10 \mathrm{mg} / \mathrm{L}$ and $12 \mathrm{mg} / \mathrm{L}$ with a mean value of the order of $11.16 \mathrm{mg} / \mathrm{L}$ (Table 1)and the recorded Bicarbonate concentrations vary between $73 \mathrm{mg} / \mathrm{L}$ and $76 \mathrm{mg} / \mathrm{L}$ with an average value of $74.2 \mathrm{mg} / \mathrm{L}$ (Table 1 ).

\section{Discussion:}

Physico-chemical parameters:

Temperature:

The recorded water temperature values are between $28.8^{\circ} \mathrm{C}$ and $31.2^{\circ} \mathrm{C}$

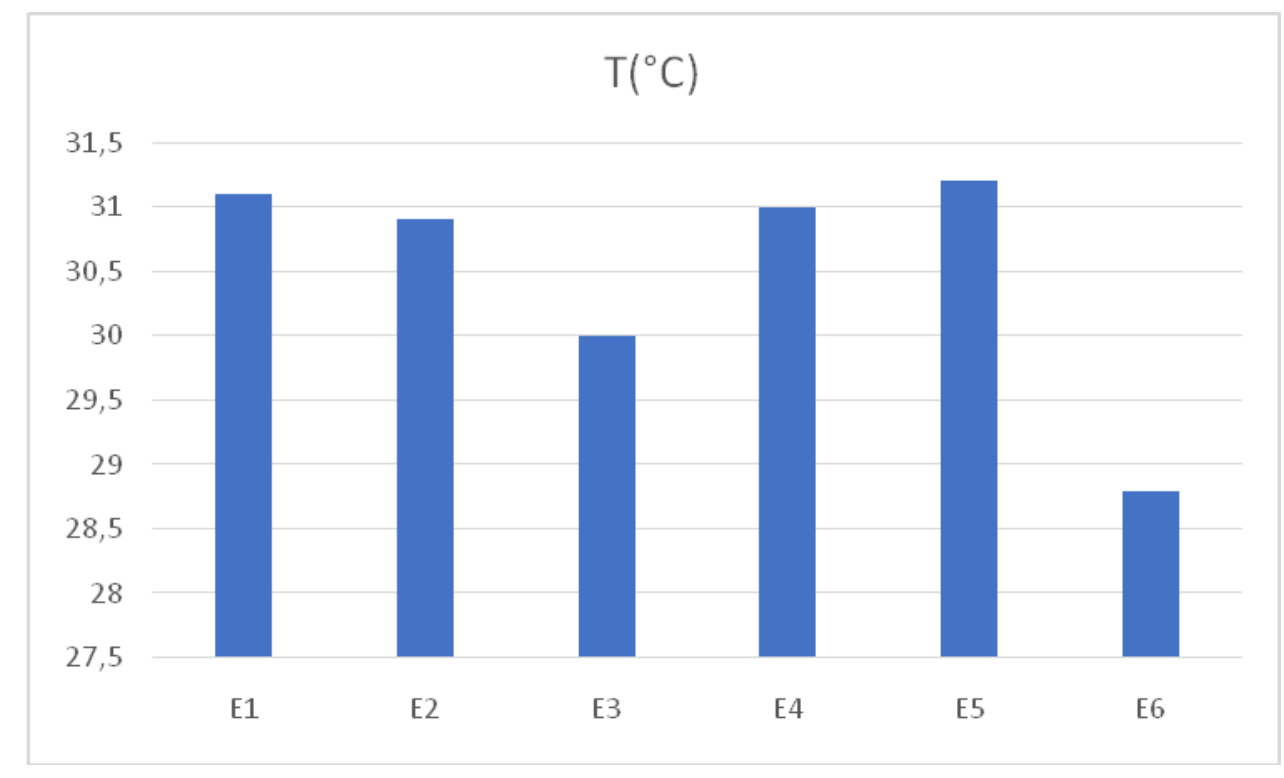

Figure 2: Variation in Temperature values

The average value of the Temperature of the water produced is $30.5^{\circ}$, this value belongs to the middle class of the surface water quality grid this can be explained by the climate of the semi-arid zone.

pH:

The $\mathrm{pH}$ indicates the alkalinity of water, it's role is crucial for the growth of microorganisms which generally have an optimum $\mathrm{pH}$ ranging between 6.5 and 7.5 . when the $\mathrm{pH}$ is less than 5 or greater than 8.5, the growth of microorganisms is directly affected. In addition, $\mathrm{pH}$ is an important element for the interpretation of corrosion in the pipelines of desalination plant and distribution network installations. The $\mathrm{pH}$ values measured vary between 5.47 and 8.4 with an average value of the order of 6.95 . 


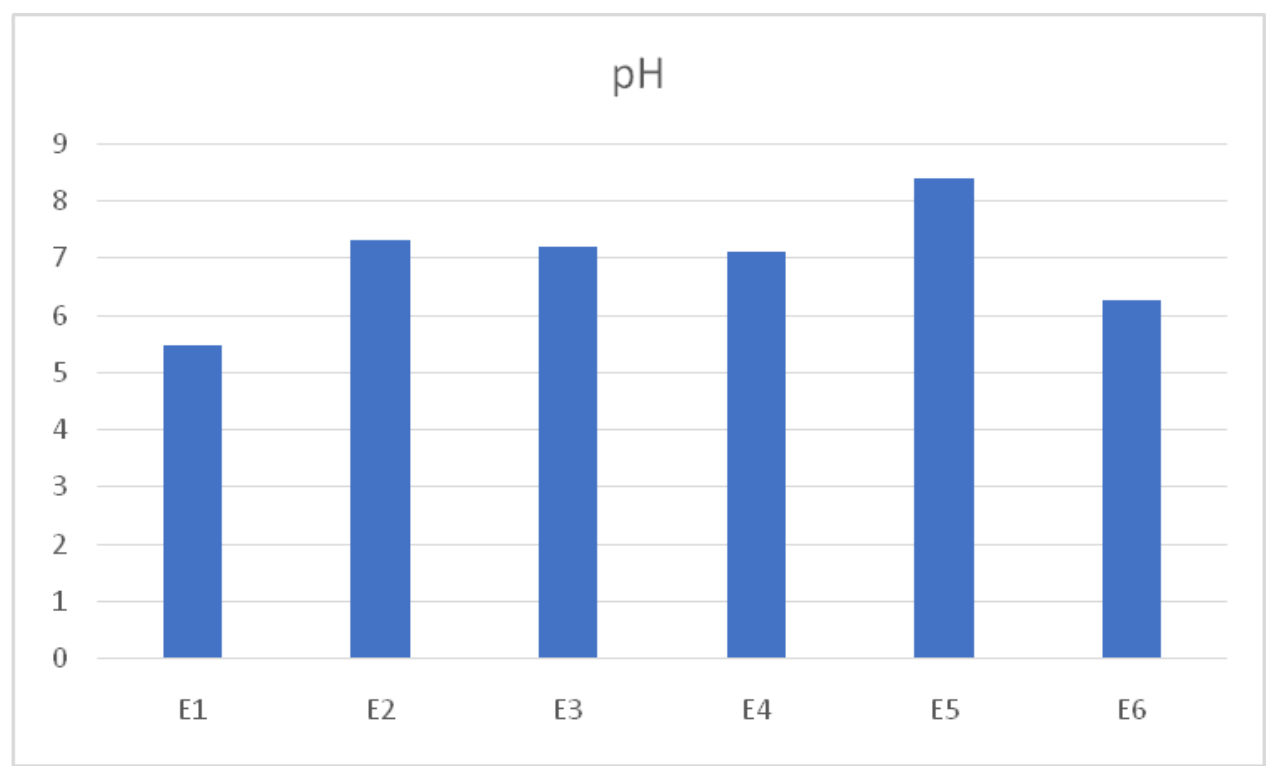

Figure 3: Variation of $\mathrm{pH}$ values

This average $\mathrm{pH}$ value meets WHO standards.

\section{Electrical conductivity:}

Electrical conductivity is probably one of the simplest and most important for controlling water quality. It reflects the degree of global mineralization, it tells us about the rate of salinity. It is a numerical expression of the capacity of the water to conduct the electric current measured in microsiemens per centimeter. The conductivity values obtained are less than $2000 \mu \mathrm{S} / \mathrm{cm}$ considered as the limit value recommended by the WHO for drinking water (8) (Table 2).

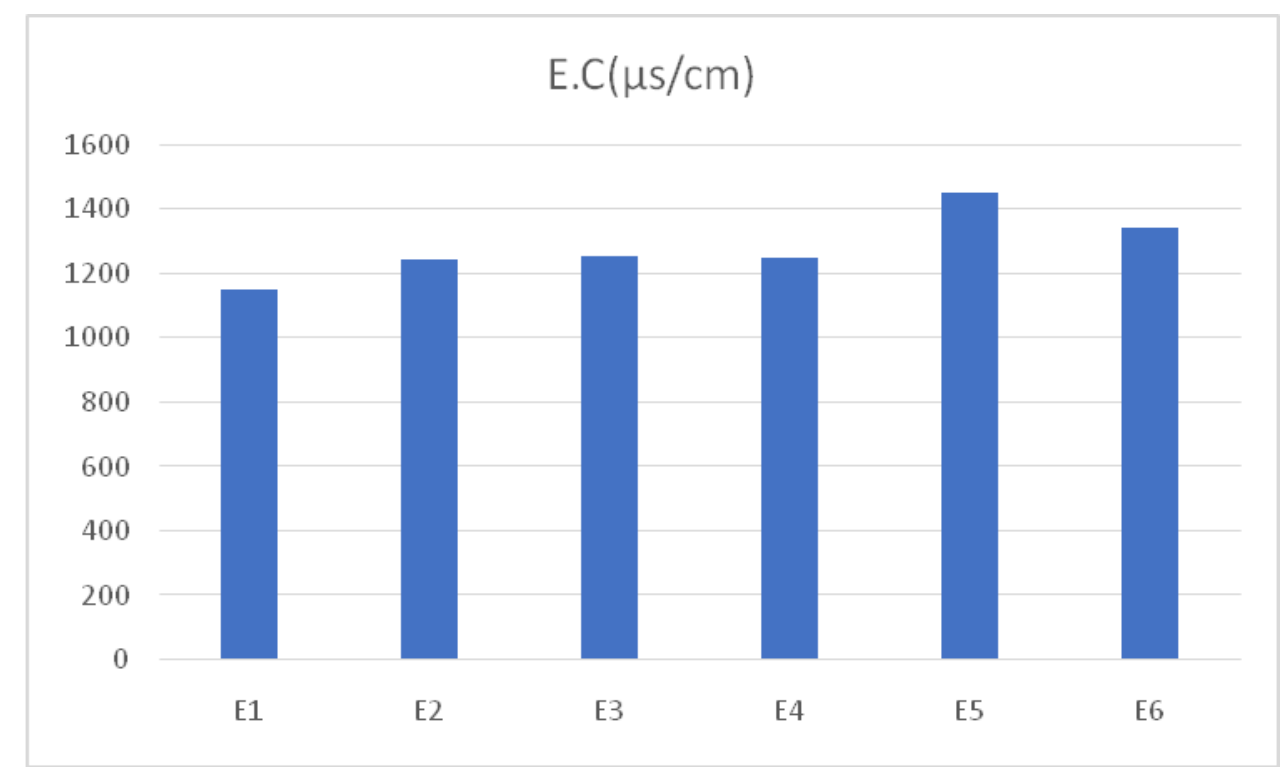

Figure 4: Variation in values of Electrical Conductivity 
Table 2:Limit values recommended by WHO for drinking water.

\begin{tabular}{|c|c|c|}
\hline parameter & Unit & WHO standard \\
\hline $\mathrm{T}$ & ${ }^{\circ} \mathrm{C}$ & \\
\hline $\mathrm{pH}$ & & $6,5-9$ \\
\hline E.C & $\mu \mathrm{S} / \mathrm{cm}$ & 2000 \\
\hline Turbidity & NTU & 5 \\
\hline TDS(Total Dissolved Salts) & $\mathrm{g} / \mathrm{L}$ & 1 \\
\hline $\mathrm{NO}_{2}^{-}(\mathrm{mg} / \mathrm{L})$ & $\mathrm{mg} / \mathrm{L}$ & 0,02 \\
\hline $\mathrm{NO}_{3}^{-}(\mathrm{mg} / \mathrm{L})$ & $\mathrm{mg} / \mathrm{L}$ & 50 \\
\hline $\mathrm{NH}_{4}^{+}(\mathrm{mg} / \mathrm{L})$ & $\mathrm{mg} / \mathrm{L}$ & 0,05 \\
\hline $\mathrm{Cl}^{-}(\mathrm{mg} / \mathrm{L})$ & $\mathrm{mg} / \mathrm{L}$ & 250 \\
\hline $\mathrm{SO}_{4}{ }^{2-}(\mathrm{mg} / \mathrm{L})$ & $\mathrm{mg} / \mathrm{L}$ & 250 \\
\hline $\mathrm{Ca}^{2+}(\mathrm{mg} / \mathrm{L})$ & $\mathrm{mg} / \mathrm{L}$ & 150 \\
\hline $\mathrm{Mg}^{2+}(\mathrm{mg} / \mathrm{L})$ & $\mathrm{mg} / \mathrm{L}$ & 50 \\
\hline Total Hardress $\left({ }^{\circ} \mathrm{f}\right)$ & ${ }^{\circ} \mathrm{f}$ & 30 \\
\hline $\mathrm{Na}^{+}(\mathrm{mg} / \mathrm{L})$ & $\mathrm{mg} / \mathrm{L}$ & 150 \\
\hline $\mathrm{K}^{+}(\mathrm{mg} / \mathrm{L})$ & $\mathrm{mg} / \mathrm{L}$ & 12 \\
\hline $\mathrm{HCO}_{3}^{-}(\mathrm{mg} / \mathrm{L})$ & $\mathrm{mg} / \mathrm{L}$ & 300 \\
\hline
\end{tabular}

TDS:

The TDS measurements in this study show values that are between $0.57 \mathrm{~g} / \mathrm{L}$ and $0.65 \mathrm{~g} / \mathrm{L}$, with an average value of $0.61 \mathrm{~g} / \mathrm{L}$.

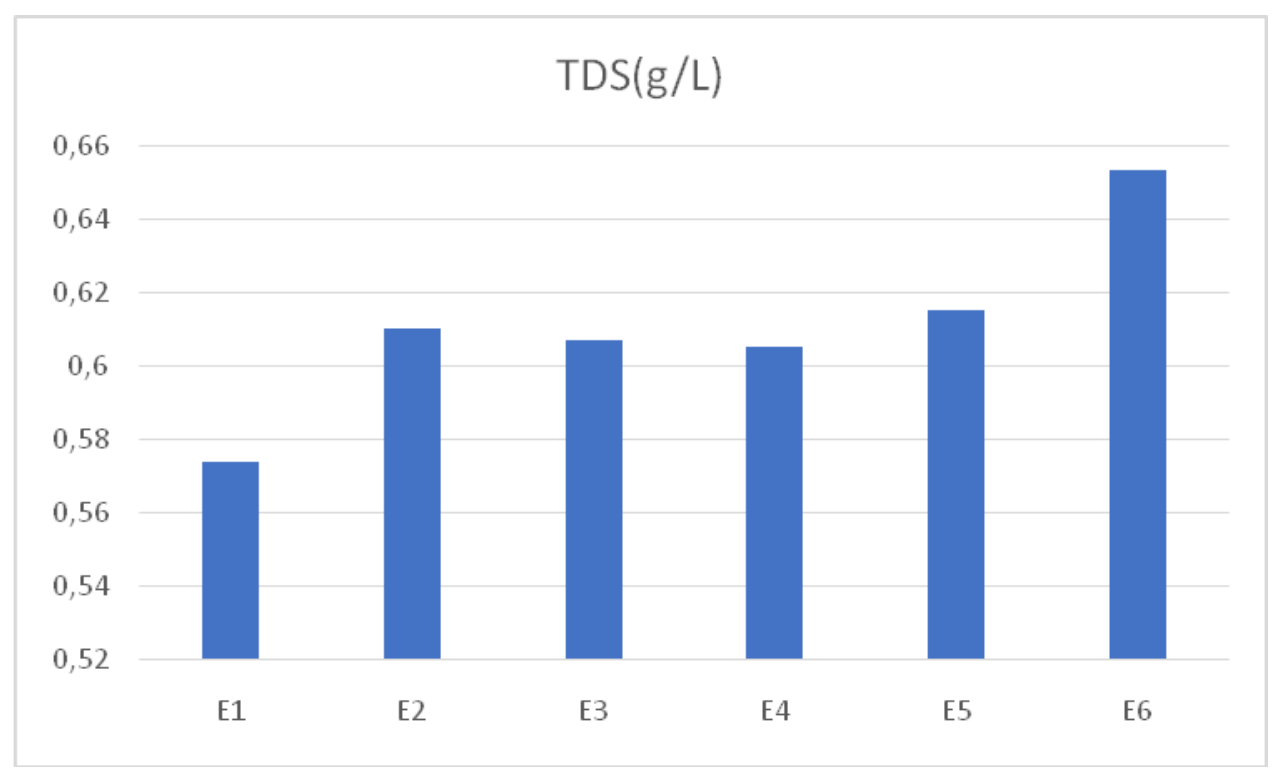

Figure 5: Variation of TDS values

These recorded TDS values of the produced water of this seawater desalination unit are therefore still below the WHO recommended drinking water limit of $1 \mathrm{~g} / \mathrm{L}$. 


\section{Turbidity:}

The most important health effect of turbidity is probably its ability to protect bacteria and viruses against disinfection (9). The infectious hepatitis epidemic in Delhi, India, attributes to mass communication from a source of raw water supplying a wastewater treatment plant, was also accompanied by a significant increase in the turbidity of the raw water (10). The very high presence of indicator germs of fecal contamination, is probably a threat to the inhabitants who draw the water needed for most of their needs (11), the turbidity value of all samples is always less than 5NTU set as limit value for water drinking water by the WHO.

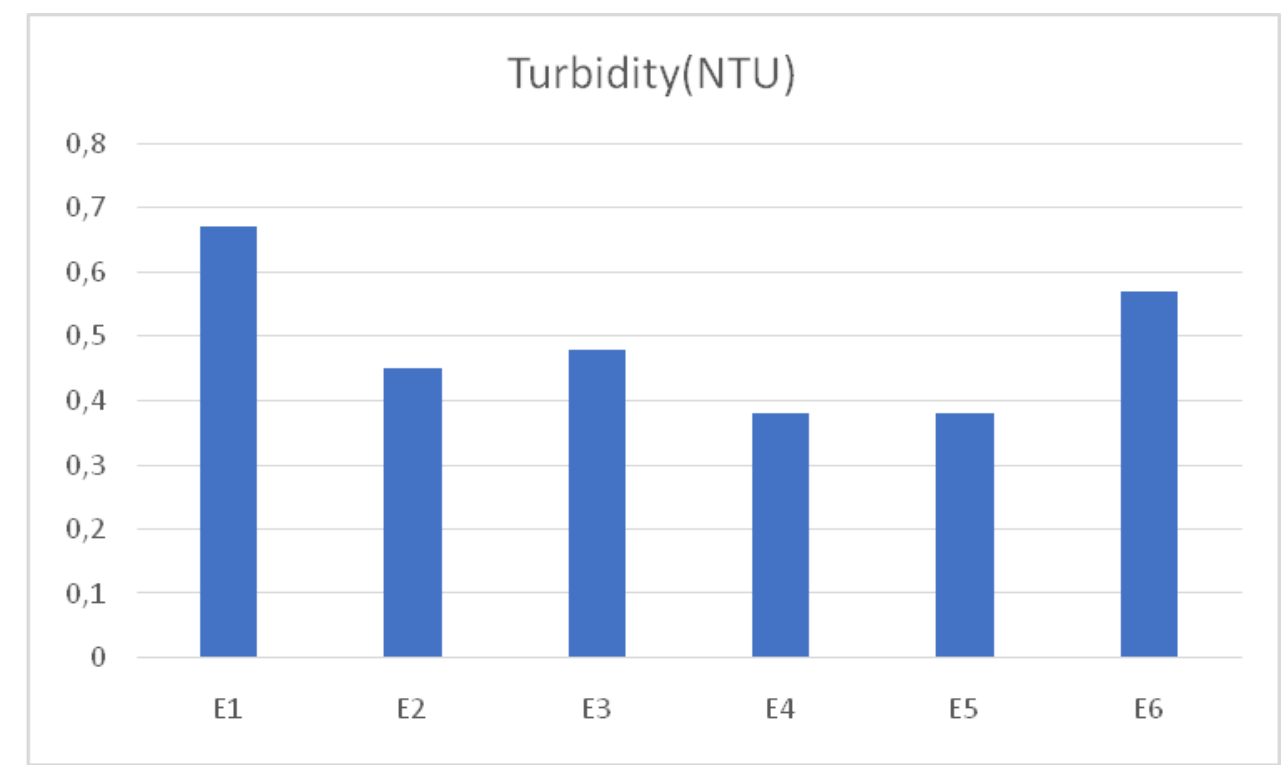

Figure 6: Variation in Turbidity values

\section{Nitrogen compounds:}

Nitrogen, which includes Ammonium $\left(\mathrm{NH}_{4}{ }^{+}\right)$, Nitrites $\left(\mathrm{NO}_{2}{ }^{-}\right)$and Nitrates $\left(\mathrm{NO}_{3}{ }^{-}\right)$, constitutes the major part of the total nitrogen. Nitrate levels in the samples in this study vary between $0,06 \mathrm{mg} / \mathrm{L}$ and 0.86 $\mathrm{mg} / \mathrm{L}$ with an average concentration of the order of $0.37 \mathrm{mg} / \mathrm{L}$, and are therefore less than $50 \mathrm{mg} / \mathrm{L}$ fixed by WHO as a limit value for drinking water (Table 2).

Nitrites are an important step in the metabolism of nitrogen compounds; they also fit into the nitrogen cycle between Ammonium and Nitrates. Nitrites generally come either from incomplete degradation of Ammonia or from Nitrate reduction, they represent only an intermediate stage and easily oxidized into Nitrates (chemically or bacterially).

The low concentrations of Nitrites in the samples of this study can be explained by the fact that this ion is an intermediate compound, unstable in the presence of oxygen, whose concentration is generally much lower than that of the two forms which are related to it, Nitrate ions and Ammonium (12). 


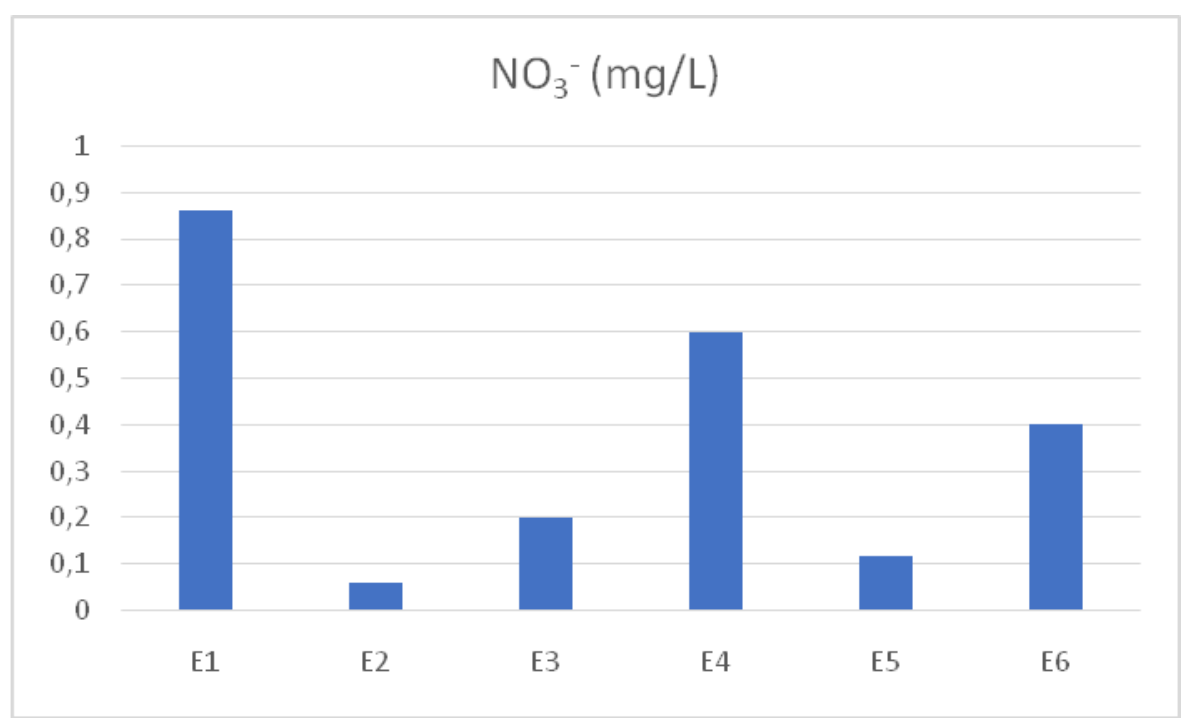

Figure 7: Variation in Nitrate Values

Sulfate:

For all samples, the Sulfate ion varies between $0 \mathrm{mg} / \mathrm{L}$ and $5 \mathrm{mg} / \mathrm{L}$, with an average value of $3.66 \mathrm{mg}$ /L(Table 1).

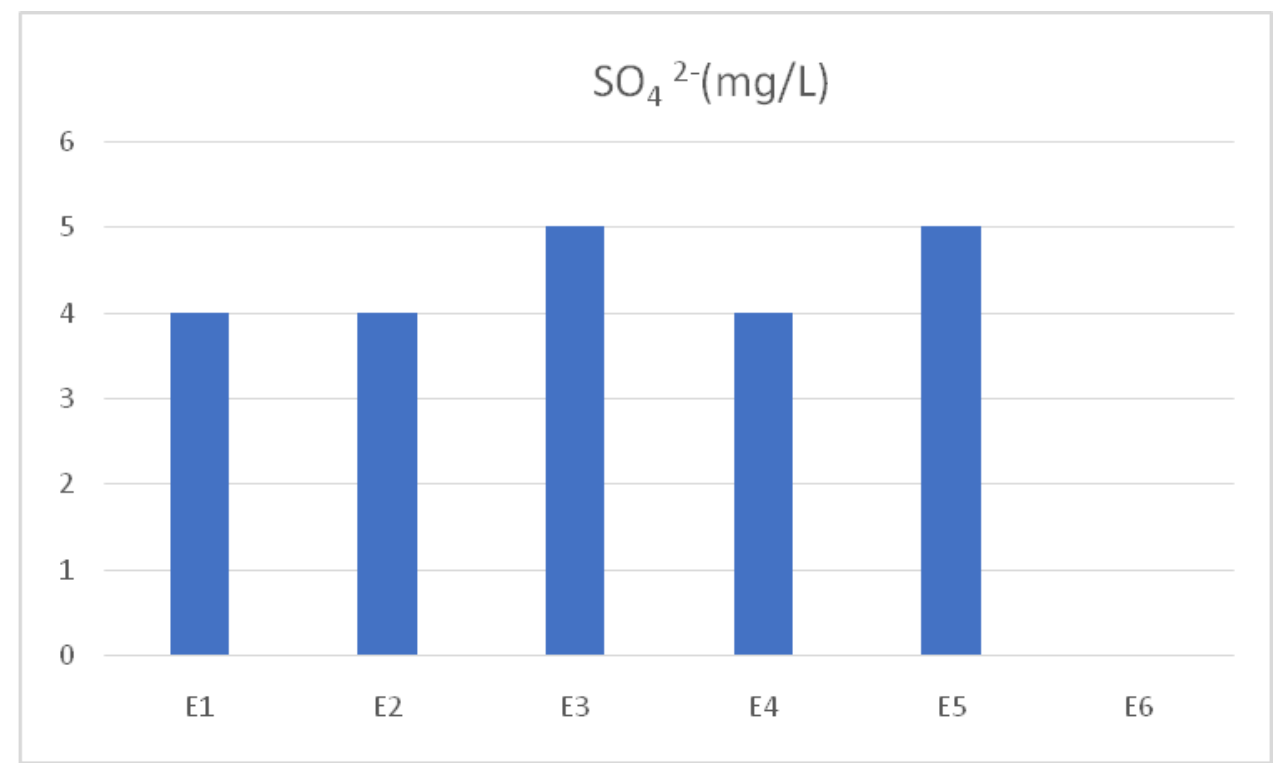

Figure8: Variation of Sulfate values

These Sulfate values for produced water are less than $250 \mathrm{mg} / \mathrm{L}$, set by the WHO as the sulphate limit value for drinking water (Table 2).

\section{Total Hardness (TH):}

In this study, the total hardness $(\mathrm{TH})$ contents varied between $1.4{ }^{\circ} \mathrm{f}$ and $3.4{ }^{\circ} \mathrm{f}$ with an average value of the order of $2.16^{\circ} \mathrm{f}$. 


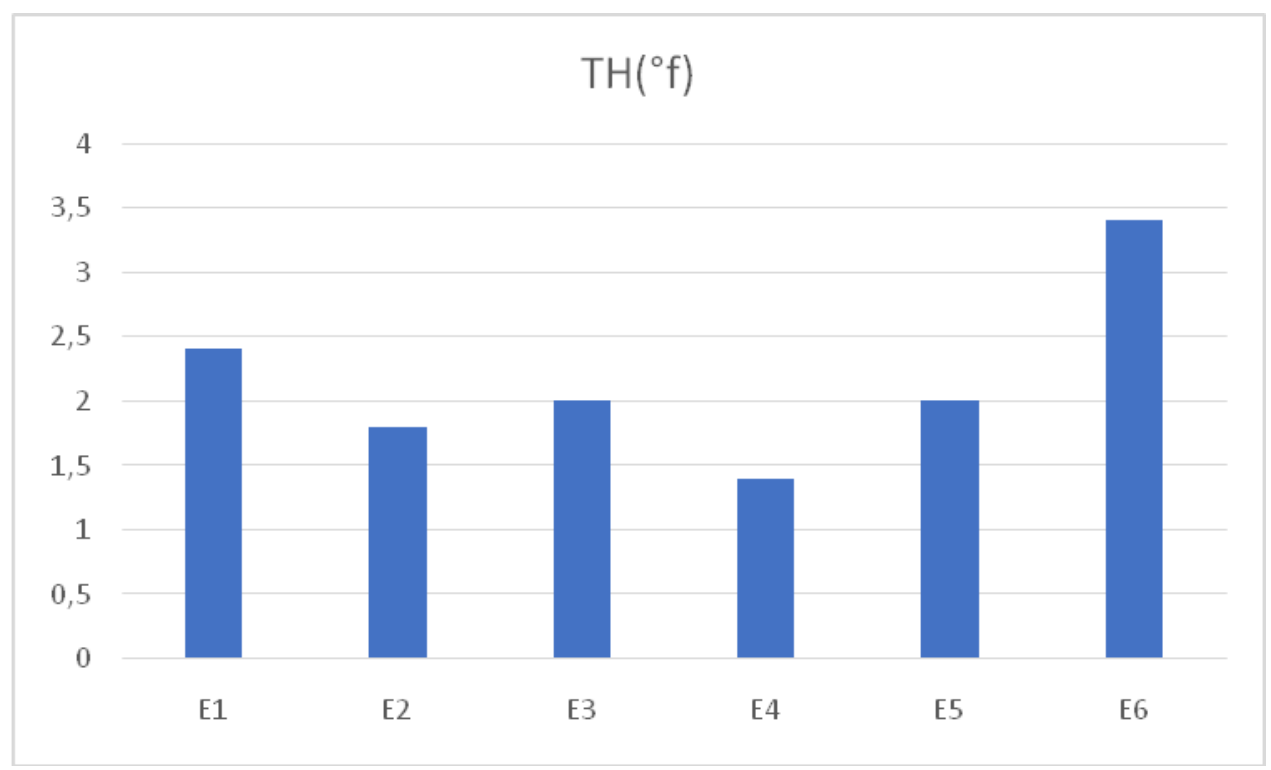

Figure 9: Variation in Total Hardness (TH) Values

These values of the Total Hardness are below $30^{\circ} \mathrm{f}$ set by the WHO as limit value in $\mathrm{TH}$ for drinking water.

\section{Sodium:}

Sodium contents for all samples vary between $66 \mathrm{mg} / \mathrm{L}$ and $78 \mathrm{mg} / \mathrm{L}$, with an average thief of $73.16 \mathrm{mg} /$ $\mathrm{L}$, so they are below $150 \mathrm{mg} / \mathrm{L}$ set by $\mathrm{WHO}$ as the limit value for drinking water.

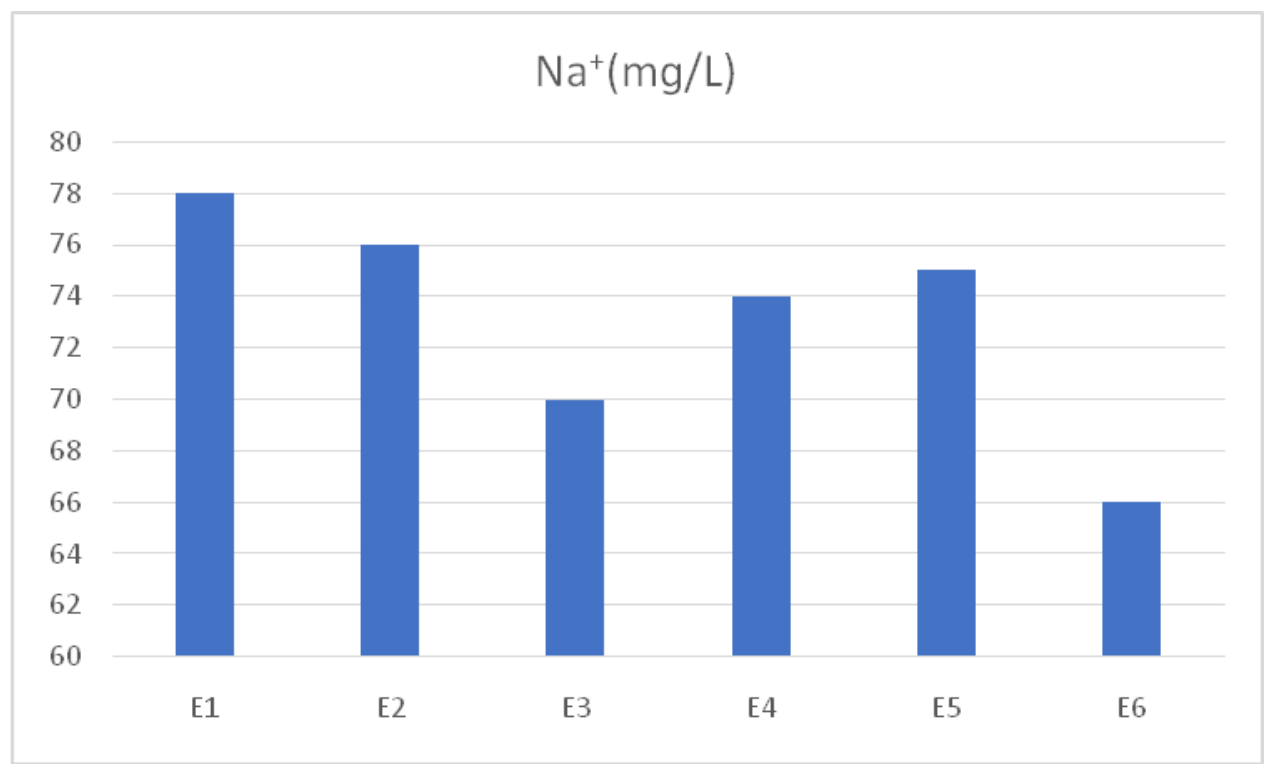

Figure 10: Variation of Sodium Values 


\section{Potassium:}

For the samples in this study, potassium levels range from $10 \mathrm{mg} / \mathrm{L}$ to $217 \mathrm{mg} / \mathrm{L}$ with an average value of $11.16 \mathrm{mg} / \mathrm{L}$ (Table 1), which is less than $12 \mathrm{mg} / \mathrm{L}$ as determined by WHO as Potassium Limit Value for Drinking Water (Table 2).

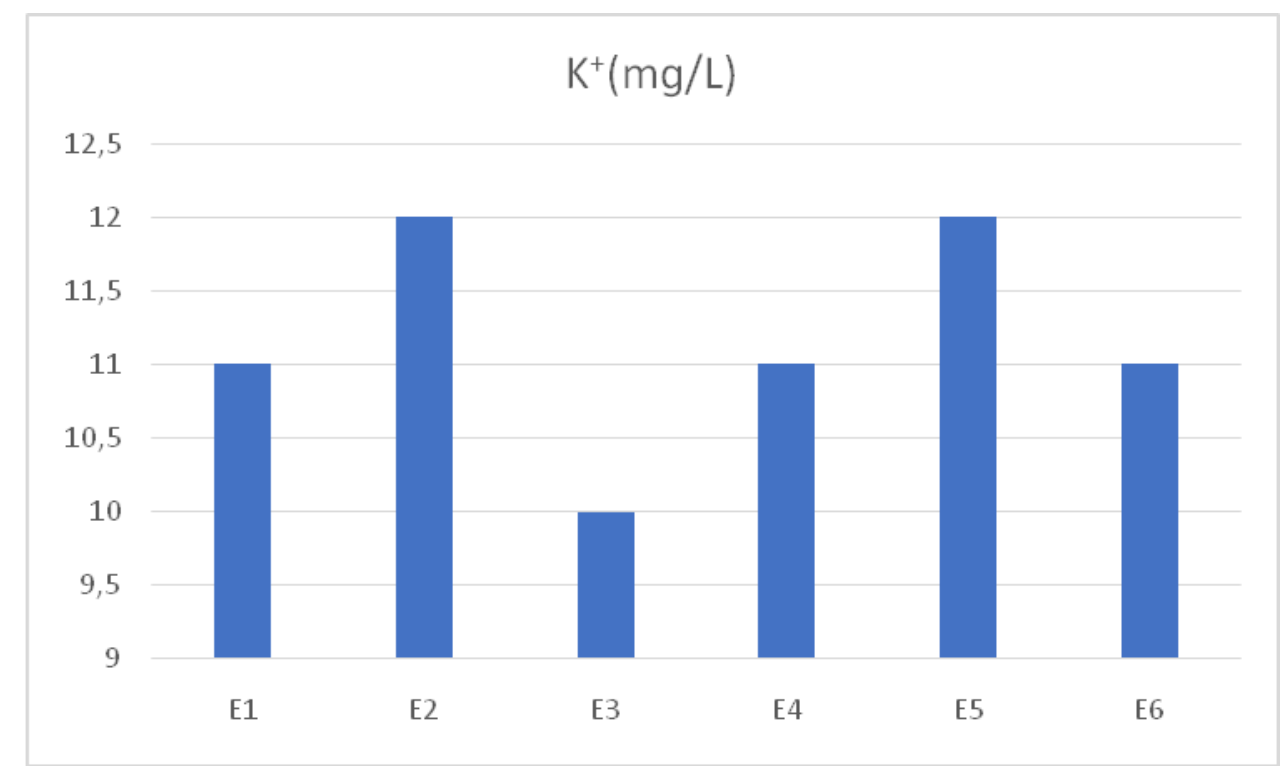

Figure 11: Variation of Potassium values

\section{Chloride:}

Chloride levels in samples ranged from $355 \mathrm{mg} / \mathrm{L}$ to $426 \mathrm{mg} / \mathrm{L}$ with an average value of $381.03 \mathrm{mg} / \mathrm{L}$ (Table 1).

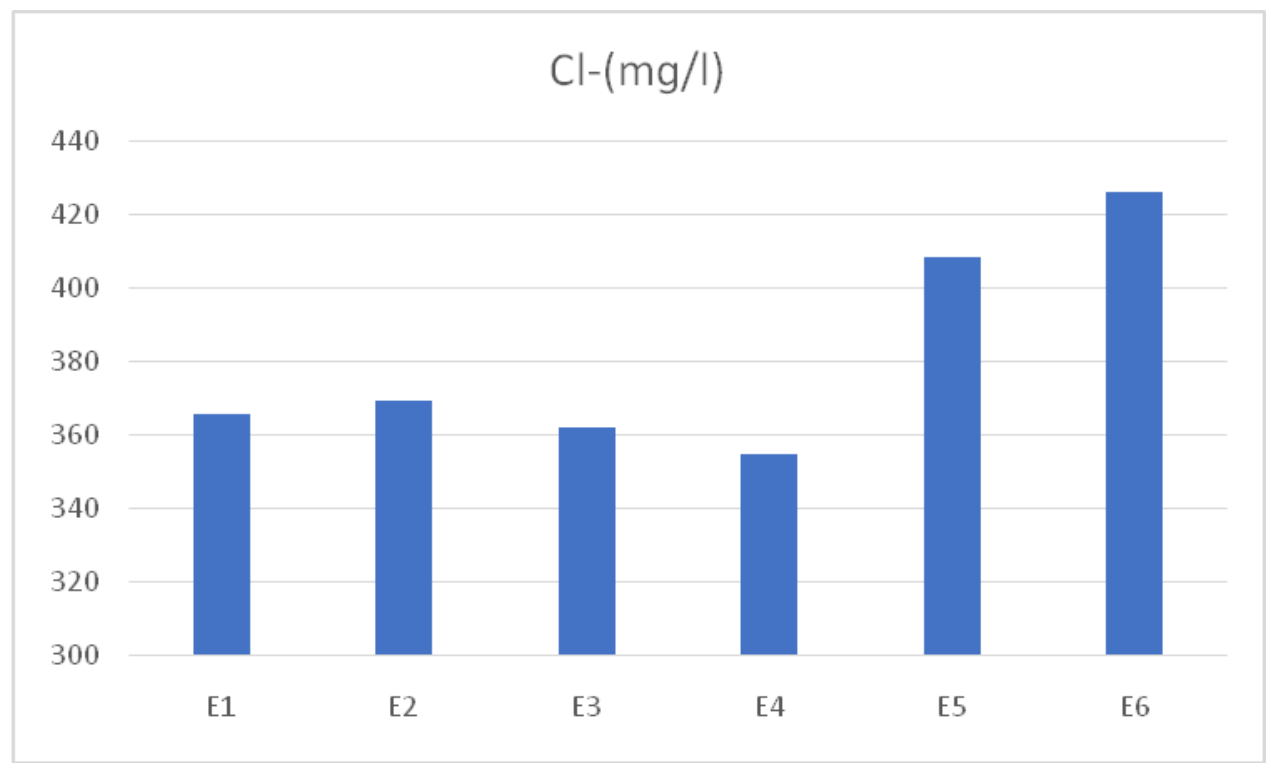

Figure 12: Variation of Chloride values 
These Chloride values therefore all exceed $250 \mathrm{mg} / \mathrm{L}$ set by the $\mathrm{WHO}$ as the limit value for chlorides for drinking water (Table 2).

This overrun can be explained by the passage of chloride through the membranes of the unit.

\section{Bicarbonate:}

The concentration of carbonates $\mathrm{CO}_{3}{ }^{2-}$ and Bicarbonates $\mathrm{HCO}_{3}{ }^{-}$in water is a function of the $\mathrm{CO}_{2}$ content, because the latter is very soluble in water (200 times more than oxygen) and its solubility depends on the temperature $\mathrm{CaCO}_{3}$ is not very soluble in water, however, the presence of $\mathrm{CO}_{2}$ gives the water a much greater dissolving force by converting calcium carbonate to calcium bicarbonate, which is more soluble in water. water according to the following reaction:

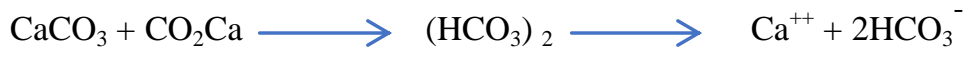

Bicarbonates contents for all samples ranged from $73 \mathrm{mg} \mathrm{L}$ to $76 \mathrm{mg} / \mathrm{L}$ (Table 1).

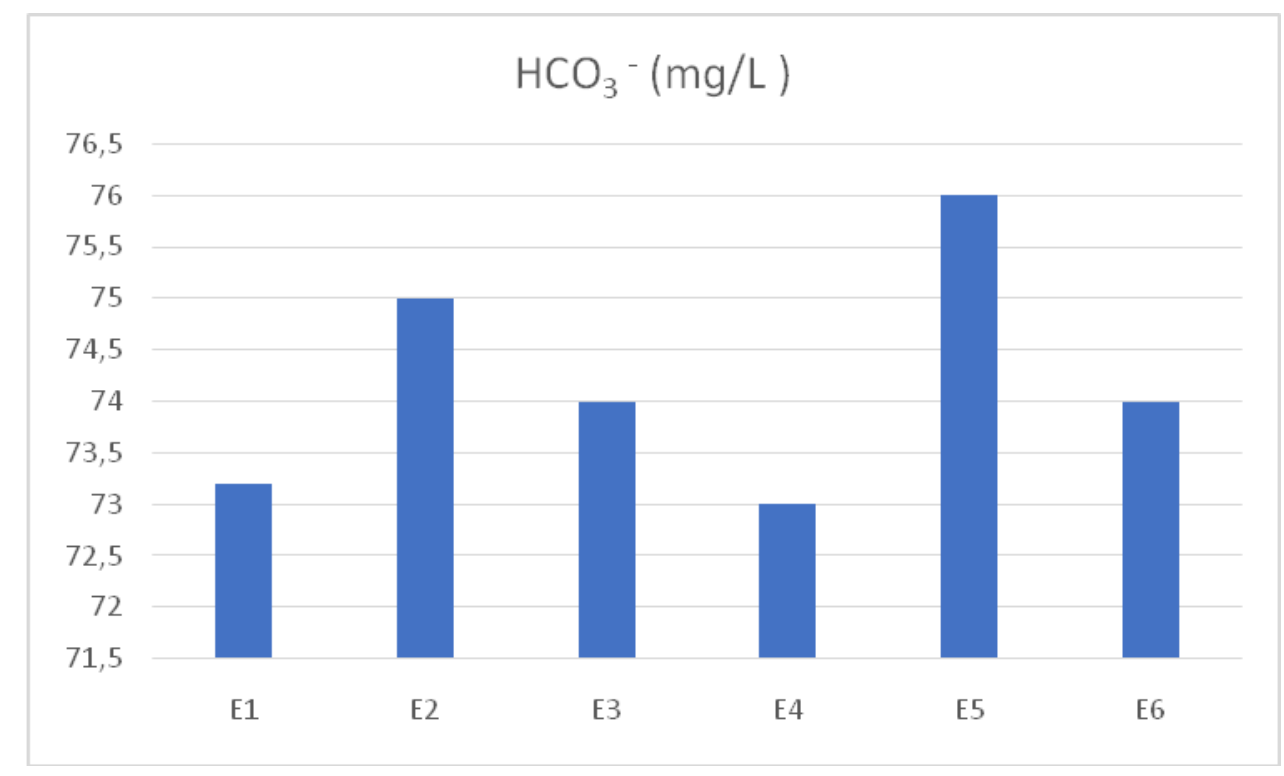

Figure 13: Variation of Bicarbonates Values

These values are therefore less than $300 \mathrm{mg} / \mathrm{L}$ set by WHO as a limit value for drinking water (Table 2).

\section{Conclusion:}

The present work is part of the evaluation of the physicochemical quality of reverse osmosis water from the Nouamghar reverse osmosis seawater desalination unit in Mauritania.

The results of this work show that chloride levels for all samples exceed the chloride limit value set by WHO at $250 \mathrm{mg} / \mathrm{L}$ for drinking water (Table 2).

Nevertheless, the average values of the other Physico-Chemical parameters comply with the WHO standards for drinking water.

\section{Bibliographic References:-}

1. M.HalimaAmrani (2000) graduation thesis for the diploma of state engineer in agronomy. Bibliographic review on pollution on the wadiSebou p: 3 and 8 I A V Hassan II.

2. Pointe .M electrokinetic phenomena and ion transfer in membranes with low cutoff threshold, application to the treatment of brackish water, thesis University of Tours, 1996. 
3. BG PARASAD T S NARAYANA Subsurface water quality of different sampling stations with some selected parameters at. machilipatnam Town, Nat Env .Poll.Tech,3(1),(2004),47-50.

4. J Maigret et A .OuldAbdallahi, «Imragun fishery on the Banc d'Argun and Cape Timiris (Mauritania): techniques and methods of fishing "in African note, 1976, No. 149, p.1-8.

5. Robert Vernet, «the FoumArguin industry (northwest Mauritania): an epipaleolithic culture of the western Sahara between Cape Juby and Cape Timiris ", Sahara, 2004, note, p.75-82.

6. General Population and Housing Census (RGPH) 2000.

7. J.RODIER, Analysis of water, natural waters, residiary waters, seawater, 7th edition paris (1984): 67p.

8. Analysis of water, natural waters, residiary waters, seawater, 7th edition paris (1984): 67p.

9. P-JAGALS, WORK, GRABOW and JC.DeVILLIERS.Evaluation of indicators for assessment of human and animal fecal pollution of surface runoff, Wat,SCi,Tech,31,(1995).

10. SC.JAMES,Metals in municipal landfill leachate and their health effects,Am.J.Public,67,(1977),429.

11. K. ;.UDERT.TQ.LQRSEN. ;.BIEBOZ.GUJER. Ureahydrolysis and precipitation dynamics in a urine-collecting systeme.Water Res,37,(2003)2571-2582.

12. Thomas (( Metrology of residiary waters). Ed.Cebedoc / Tech.and Doc.11, Liege -75384 (1995) Paris.). 